\title{
システム信頼性の最近の話題から
}

\section{Current Topics in System Reliability}

\author{
福田収一 Shuichi FUKUDA
}

アブストラクト 急速に進展する多様化、激化する状況変化により、システム信頼性の研究は、従来の設計者中心から、ユー ザ中心へと移行し、これまでの文脈独立のコマンド方式から脱却し、ユーザの意図、期待を察知し対応できる文脈依 存のシステム開発が求められている。そのために、人間の特性に注目した研究を今後進める必要がある。

キーワード ユーザ中心、信頼、意図理解、期待、人間特性

\section{1. はじめに}

最近トラスト (trust) がシステム信頼性分野で話題となって きた。トラストは，いろいろな意味で使用される。例えば， インターネットのトラストは, 従来の信頼性工学の議論の枠 を超えた，信頼 (trust)，信頼感の問題である.

これまでの信頼性工学では, ミッションを想定し, そのミッショ ンが十分に遂行できるかどうかを基準に議論を行った。しかし, これが可能であった理由は, 状況変化が少なかったからである. もちろん，デバイス信頼性の問題は別である. デバイスであれば, 当然想定ミッションがあり，急速に発達しているデバイスの信頼性 工学の成果を応用することができる.

しかし, システム信頼性の場合は, システムの稼動環境， 条件が，極言すれば時々刻々変化する状況となってきた。し たがって, 従来のように設計者がシステムのミッションを事 前に十分に予測することが急速に困難となってきている．想 定ミッションが実施できる状況であれば，そのミッションが 十分に達成できるかどうかで信頼性を論じることができる. しかし, ミッションが時々刻々変化する場合には, むしろ何 がミッションであるかを判断することが重要となってきた。 状況の変化, 現況を判断できるのはユーザしかいない。した がって, システム信頼性は, 設計者主体からユーザ主体へと 大きく変化しつつある.

ユーザ主体のシステム信頼性の問題とインターネットのト ラストの問題は深く関係している。両者とも，ユーザが対象 を信頼 (trust) できるかどうかの問題である，いずれも，境界 が設定できないオープンエンドで, ユーザが, 自分の期待ど おりの結果が得られるかどうかが問題となる.

システムが余りにも複雑化, 多様化し, ユーザが詳細を理 解することは不可能に近い。したがって，ユーザにとっては， 状況が変化したときに, システムが自分の判断, 意思決定の

福田収一 正員 スタンフォード大学 デザイン ディビジョン

E-mail_shufukuda@cdr.stanford.edu

Shuichi FUKUDA, Member (Stanford University, Design Division, Palo Alto, CA, 94301 USA).

Fundamentals Review Vol.1 No.4 pp.62-69 2008年4月
役に立つか, 更に, 自分の決定に従い適切に対応するかが重 要となる。判断, 意思決定, 行動は人により異なる。したがっ て, システムへの期待もユーザ，ユーザで異なる。期待した とおりに動作することが信頼を生む.

本稿では, 航空機から出発して, システム信頼性とトラス トの問題を考えてみたい.

\section{2. 航空幾の信頼性}

商用の定期便の航空機は, システムが複雑であるが, 想定 されるミッションは明確である。ただし，環境が大きく変動 するのでオープンエンドの問題である.

航空機の事故は, 大部分がヒューマンエラーに起因する ${ }^{(1)}$. 興味深いことは, 航空機では, CFIT (Controlled Flight into Terrain) が大きな問題となっている. CFITとは, 航空機は正 常に作動しているのに，地上に衝突する事故である。すなわ ち, ミッションが明確であり, システム, 作業内容を熟知し ているプロのパイロットが, 飛行機を適切に操縦できずに事 故を起こしている。これは, システムを適切に設計しても, 本当に信頼性が確保できるのかという大きな問題を提起して いる。

特に定期便の場合は，通常のシステムのユーザとは全く異 なり，プロであるから，多くの訓練を受けマニュアルも完備 している。それにもかかわらず，システムとしての信頼性が 確保できない, すなわち, システム信頼性においては人間 という要素を十分に考慮しなければならないことを示してい る.

そのため, 航空分野ではヒューマンエラー防止のために多 くの方法が開発されている。特にNASAが 1979年に開発した CRM (Crew Resource Management) (2) は有名である.CRMは， リーダーシップ, コミュニケーション，意思決定の重要性を 強調している.

航空機事故のヒューマンエラーには, S (Software), H (Hardware), E (Environment), L (Liveware, 人間要素) が関 


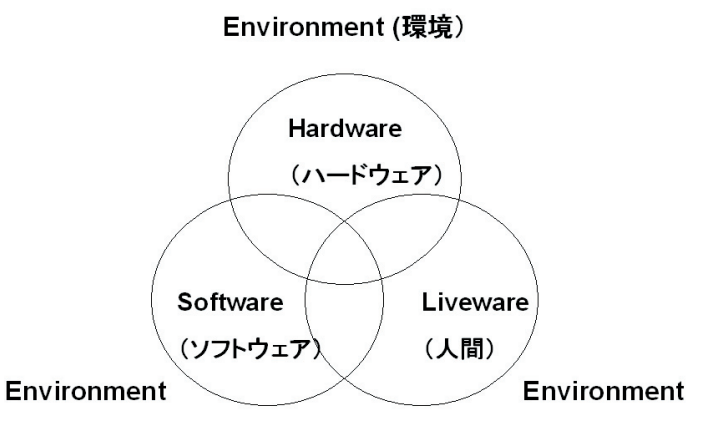

図1 SHEL (Software, Hardware, Environment and Liveware) モデル

与し，特にその間のインタフェースが重要であるとの認識か ら SHEL モデル (図1) がElwin Edwardsにより 1972年に開発さ れ，その後H. F. Hawkinsによって改良された ${ }^{(3)}$. Edwardsは， 主として，それら要因間のインタフェースに注目した。

Edwardsが検討した対象は, 軍用, 商用の定期便などのプ 口の航空業界である。しかし，たとえプロの航空業界にして も，世界的に見れば，次第にLCC (Low Cost Carrier)，すなわ ち，小型機の時代となり，また商用でも，ビジネスジェット やエアタクシーが盛んとなろうとしている現在, 運航形態は 急速に多様化してきている，更に，個人の自家用機も急速に 増大している現状を考えるならば, 要因間だけではなく, 要 因そのものも改めて検討してゆかなければならない時代が来 ている.

SHEL モデルは, S (ソフトウェア) ,H（ハードウェア）,E（環 境)，L (人間)の要因とその相互作用を考えるモデルである から，航空機に限らずシステム一般の信頼性を論じる基本モ デルであると考えることができる。

ただし，元々のSHEL モデルは，E（Environment，環境）に 文脈 (Context) を明示的に含めていない。しかし，状況が急 激に変化し, 更に多様化が急激に進む現状，また意思決定， 評価など人間の要素が重要となってきていることを考えるな らば，Eに環境として文脈も含めて考えるべきである。

本稿では，この広義の SHEL モデルを基礎に，最近のシス テム信頼性の問題を考えてみたい。

\section{3. 人間の問題}

\section{1 コミュニケーションの問題}

CRM はコミュニケーションが重要との認識から開発され た。インターネットのトラストの問題も，コミュニケーショ ンの問題である。人は，相手を信用して初めて本音を言う。 どうして相手が信用できると分かるのか？これは認識論の問 題である。顔も声も聞こえない情報をどうしたら信用できる か?

人は言葉だけではなく, 顔や声から信用できるかどうかを 判断している(4). 言葉は, その表面的の意味からだけでは理 解ができない，真の意味，話者の意困を理解するためには， 話者の話し方 (paralanguage) に注目をする必要がある。更に，
その表情を観察することも必要である。最近, 人間の知性を 本当に理解するためには, 感情までも考慮する必要があると の指摘があり, Emotional Intelligenceが注目を浴びている(5). こ れも同様の理由である。単なる言語コミュニケーションでは なく, 感情コミュニケーションが意眓理解において重要な役 割を果す.

すなわち, 真の意困は, 言葉ではなく, 感情を理解して, 初めて察知できる。 今までの知性の議論, 言語コミュニケー ションは, 文脈独立であったが, 感情を理解し, 真の意眓を 察知するためには, 文脈を理解しなければならない。 そのた めに感情が果たす役割は大きい.

ネットワークの信頼度がいかに高くても, また情報のセ キュリティがいかに高くても，その情報自体が信用できるか どうかとは全く別の問題である。情報は, 未知であるから こそ情報として価值がある。したがって，それを信頼，信 用 (trust) するかしないかには，感情が大きく影響する。言葉 上で非常に良いことを言っていても，その話し方，表情など から真の意罒が推定され，その情報の価值が判断される。そ の意味でインターネットの信頼 (trust) の問題はコミュニケー ション, 特に感情コミュニケーションの問題であることに留 意する必要がある。

感情コミュニケーションが重要な役割を果すことはUA232 の事故例がよく示している。この事故はCRMが最も良い成 果を収めた例として有名である。UA232 はアイオア州のスー シティ市の上空を飛行中, 4個のエンジンのうちの3個のエン ジンがダメになりながら, 無事着陸し, 大半の乗客を生還さ せた ${ }^{(6)}$.

3個のエンジンがダメになったとき, 機長と副操縦士はも うおしまいだと思ったそうである。しかし，少しして，我に 返ったときに，「今飛んでいるのは，平地のアイオアだ。ロッ キーの山の上でもなければ，海の上でもない，どこも平地な のだから, どこも飛行場じゃないか! 何て自分たちは幸運な んだ!」とパイロットは思ったという, まさにポジティブシ ンキングの典型である. そして, 極めて冷静な管制官とコミュ ニケーションをしているうちに,「自分が操縦しているのは, DC10だ，スロットルが独立に制御できる。それならばスロッ トルをそれぞれ調整しながら, 着陸できる」と考えて無事着 陸できたと述べている.

このパイロット, Al Haynesの優れた点は, 自分は管制官 とのコミュニケーションと意志決定に集中し, 操縦を完全に 副操縦士に任せたことである。すなわち，ロールプレイング (role playing) が完全であった。興味深いことに彼は，「自分 はLOFT ${ }^{(7)}$ の訓練を受けているのだから，このような事態に 対応できないはずはないと考えた」と述べている。そのよう に考えたときに，自分の気持ちに余裕ができ適切な判断がで きたという。すなわち，LOFTの訓練が彼に自信 (confidence) を与えたことになる。更にもっと興味深いことには，実は LOFTの訓練シナリオには, この例のような事故のシナリオ はなく，彼の自信が事故を最小に食い止めた。

日本語でも英語でも信頼 (trust) と自信 (confidence) は異な 
る言葉で表現する。しかし，ドイツ語のVertrauen には，英語 の trust と confidenceの両義がある。信頼と自信は通常別と考 えられるが，このUA232の例からも自信と信頼は実は密接に 関連しているらしいことが推測される。Al Haynesは，飛行機 を信頼したからこそ，自信を持てたのであろう。

訓練が持つ意味は, 状況への対応能力, 経験を育成する だけではなく，自信を植え付け，更に，訓練の対象となる システムに対する信頼を向上させると考えることができる. UA232の事例は, 信頼性と訓練, 学習の関係を改めて検討す る必要性を示唆している。

従来，人間の問題は，余り工学とは関係がないと考えられ た。しかし，航空機事故の大半が人間に起因している事実か らも分かるように，工学に扔いても人間要素を考慮する必要 性が増大してきている。これまでの信頼性では，たとえ人間 を考慮しても，物理的要素と同じ报いをしていた。しかし， 人間は，日々学習して扬り，成長をしている。したがって， 学習しない物理的要素と同一に論じることはできない，

\section{2 ヒューマンエラー}

CRMのねらいは，第三者の目の確保にある．人はある状況 に陷ると視野が狭くなり，その考えにとらわれやすい。しか し岡目八目で, 第三者の目で状況を眺めれば, 冷静で, 適切 な判断ができる。これは本人にエラーを気付かせることにつ ながる。そこで，次にヒューマンエラーの問題を考える。

これまでのヒューマンエラーは，設計者が意罒した行動を ユーザが遂行できないことを指していた．物理的要素の場合 は，設計者の意図どおりに動作しなければシステムが動作し ない。しかし，最近のように状況が広範囲に，しかも短時間 に激しく変化するような状況では，果たして設計者は，そう した状況を事前に予測できるのかという大きな問題がある.

従来の信頼性の議論は，すべて状況が事前に予測可能であ り，その予測できる状況において性能を最大発揮することを 前提としていた。しかし，状況が予測できないとなれば，考 え方を大きく変換する必要がある。

筆者は，20世紀を鉄道の時代と例えている ${ }^{(8)}$. 鉄道の時代 であれば，線路があるので，行き先は分かる。目的地がはっ きりしている以上，問題は，いかに早く，正確に，あるいは 安く到着するかである。したがって, 戦術が重要となる。こ れに対して 21 世紀は航海の時代である，航海では，天候に応 じて航路は変更せざるを得ないし，嵐が来れば予定しない港 にも寄航しなければならない。最悪の場合は, 最終目的地も 変更しなければならない。そのときには，なぜこの航海に出 たのかという本質的な問題を考える必要が出てくる。すなわ ち, 航海では大きな目的を考える必要があり, 戦略が重要で ある。

鉄道であれば，最初に路線を選ぶことが重要である。しか し，航海では，状況に応じて，適切なときに適切な判断を下 さなければならない，従来の信頼性は，いわば鉄道であり， どの路線を選択するかについては, 多数の非常に優れた方法
が開発されている。しかし，航海の時代となると別の信頼性 技術が必要となる。それは状況を見る技術であり，ユーザ主 体の信頼性である。

\section{3 チームワーク}

状況変化が激しくなると, 行動を起こす前に, まず状況の 理解が必要となる。それにより対応が異なる。しかしどのよ うに対応するかは, 個人個人の性格, 感情に大きく依存する。 Stanfordではチーム設計においてメンバーの性格を考える ことでチームの成果が上がることを実証している ${ }^{(15)}$. 多様化 が進み, 変化が激化する状況に対応するには, 今後ますます 衆知の結集が必要となり, チーム作業が重要となる。そうし た状況にあって，チームメンバーの性格を考慮してゆくこと も信頼性向上には重要な課題であろう.

事実，CRMは，チームワークの重要性を強調している。し かし, CRMでは, メンバーの性格の問題は考虑されていない. 航空機の場合, 性格を考慮して, べストチームとなるように メンバーを組織することは，人的資源の制約から無理である としても，少なくとも性格を考慮してチームの信頼性を向上 させることはできるように思われる。

チームワークでは, 通常人間同士のチームを考える。しか し, 変化の激しい現代は, 機械と人間もチームとして協働し なければならない。明日の機械は，ユーザの不足点を補い， その行動の先を読んで対応し, 周囲状況に関する情報を提供 できなければならない。すなわち，まさに人馬一体として， これからは，機械と人間が一体となり，チームとして周囲変 化に適応してゆかなければならない。そのためには, 機械も， ユーザの特徴, 性格を把握しなければ, 必要なときに, 適切 な情報を提供できない。

\section{4. マーケット創造}

20 世紀と 21 世紀をマーケットという視点から比較してみ よう (4).20世紀は地理的マーケットを対象にした。すなわち， ある特定地域のマーケットを対象に，そこで評価される製品 を生産した。地理的なマーケットでの競争力があれば，いわ ゆるアダムスミスの見えざる手が働いて一物一価となり，製 品の価值は確定し，マーケットを制覇できた。

しかし, 広域化, 多様化が進んだ 21 世紀では. マーケット はもはや地理的に限定されていない。その代表例が, ロング テールである ${ }^{(9)}$. またWeb 2.0 の世界である.すなわち, マー ケットは創造する時代となった。

マーケットを創造する時代の信頼性は, 攻めの信頼性であ る. 20 世紀の信頼性は, まず設計要求があり, それをいかに 高レベルで実現するかに力点があった。しかし，21世紀の信 頼性は, 信頼, 信用 (trust) を売る技術となる。これはブラン ド戦略と一緒である。

品質保証も昔の品質保証は製品を保証していた。すなわち, ある製品を試験し，これだけの品質がありますと保証してい 
た。しかし，ISO 9000 は，システムの品質を保証する方式で あり，個別の製品を保証しているわけではない。システムを 可視化し，システムの品質を顧客に理解させようとする努力 である．ISO 9000 関係者はブランドとは呼ばないが，基本的 にブランド戦略である。

従来の信頼性は，昔の品質保証と同じで，個別製品につい て信頼性を保証していた。しかし，今後はシステムとして信 頼性を保証する必要がある。すなわち，システムへの信頼 (trust)を構築しなければならない。そのためには，システム の可視化が重要となる。もちろん，個別製品の信頼性確保は 不可欠である。しかし，それだけでは 21 世紀のマーケットを 確保できない。マーケットを創造するためには，ブランド戦 略が重要となる。

ブランドがなぜブランド足りえるのか？ブランドはコミュ ニケーションを通して次第に評価が確立する. ISO9000がい かに素晴らしい方式であろうと，世間がそれを認めなけれ ば意味がない，企業だけが認めても効果はない。ユーザが ISO9000の持つ意味を理解しなければ，全く意味がない．21 世紀の信頼性は，ユーザ主導の信頼性である。したがって， ユーザが信頼を置けると判断するかが基本となる.

\section{5. サービス}

\section{1 期待への対応}

21 世紀はサービス産業の時代であると言われる。しかし， 21 世紀のサービス産業は，20世紀の労働集約的なサービス産 業の延長ではない。知識集約へと変貌してゆく，

例えば，自動販売機でも，暑い日には，買いにくるお客に， 「暑いですね!こんな新しい飲物が入りましたけど，いかが です，暑い日には扎いしいですよ!」と言えば，打客は，高 くてもその飲み物を買うであろう。自動販売機に文脈を読め る機能が備わっていれば，これが可能となる。すなわち，21 世紀のサービスとは, 状況, 文脈を理解できるシステム機能 の実現である。

文脈，状況を理解できる機能が実現できれば，ユーザの状 況判断，意思決定の支援が適切に行える，元々サービスとは， 顧客の「期待」に適切に対応することである。

従来のシステムはコマンド駆動が大多数であった。実際， 何か指示しなければシステムは動作しなかった。一方，期待 を察知するとは，相手の行動の先を読むことである。それは， 観察, 経験から学習して初めて可能となる。従来の大部分の システムでは, 観察, 学習機能を考慮していない.

しかし, 後述する, ソフトウェアの継続的プロトタイピン グによる機能成長 (進化) 曲線は学習曲線に極めて類似してい る。その意味でソフトウェアの活用が期待される。

ユビキタスコンピューティング，アンビエントインテリ ジェンス (ambient intelligence) の時代となると，システムと 環境が統合され，システムに観察機能が備わる。したがって， ユーザのシステムへの期待の察知がより容易になると期待さ
れる。

現代社会は複雑で，いろいろな場面で，多くの判断が必要 となってきている。こうした時代にあって，コマンド方式で 対応してゆけば, 人は, 疲労がますます蓄積し, それに伴っ てエラーも多発するようになってくる。その意味でも，期待 を察知できるシステムの開発が急務となっている。

\section{2 サービスとエラー}

サービスの怖さは，一回の失敗が取り返しのつかない結果 を招くことがある。例えばホテルで怙客を怒らせれば，多分 その挌は 2 度とそのホテルには来ないであろう。その意味 では失敗が許されない。したがって, 最も高い信頼性が要求 される分野がサービス産業であると言っても差し支えない. しかし，それにもかかわらず，サービス産業分野での信頼性 の研究は極めて少ない.

しかし, 失敗 (failure) とエラー (error) は違う。失敗は取 り返しがつかないが，エラーは回復可能である。ホテルでも， 予約した部屋に宿泊できなくても，その代わりに上級の部屋 に宿泊できれば，お客は満足し，ホテル側のエラーを失敗と はみなさないであろう。

エラーからの回復は, サービス業で重要であるが, 実は工 学の世界でも重要である。航空のCFITの原因は人間である. 人間はエラーを絶えずしているが, そのエラーから回復する 適切な手段が用意されていないために，エラーから失敗に至 り大惨事となる。

エラーから正常に戻れる限界を考えることも可能である。 すなわち，エラーの管理限界を考えれば，それを超えると失 敗となる。人間は絶えずエラーをしている。したがって，そ のエラーをいかに限界範囲内に納めるかを信頼性確保の指針 と考えることもできる(図2).

人間がエラーから回復するには，CRMが実証するように， コミュニケーションが重要な役割を果す。しかし, システム が人間の期待にこたえるためには，人間同士だけではなく， 人間とシステム間のコミュニケーションについて考えてゆく 必要がある。

人間は, 怒りなどの情動によって，その情報処理能力が急 激に低下することが知られている ${ }^{(10)}$. また, パニック状態と なれば，人間は冷静な判断ができない。东などで，多くの 人が，別にドアがあるにもかかわらず，同じドアに殺到して 亡くなるのがその一例である。

例えば自動車の場合, 周囲状況は刻々变化し, ドライバー

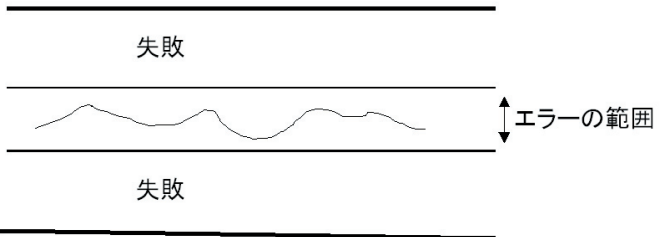

図2 エラーと失敗 
はいろいろな感情に支配される。しばしばいらいらしたり， 怒ったりする。もしドライバーが感情的に安定すれば，より 安全な運転が期待できる。しかし, 自動車の設計者は, 大枠 の使用状況は予想できても，個別の状況変化までは予想でき ない.

したがって，自動車は，まさにユーザ主導であり，ユーザ がいかに的確に状況を判断し, 適切な対応が取れるかが, シ ステムの信頼性を支配する。そこで，システムが，第3者の 目でドライバーに状況を伝える, あるいは感情コミュニケー ションを行い, 感情を和らげれば, 安全運転に大きく寄与で きると期待される ${ }^{(11),(12)}$.

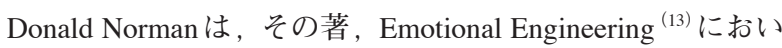
て極めて面白い指摘をしている。「昔の機械は単純であった。 したがって，ユーザはその機械の動作を予想でき，機械も指 示どおりに動いた。したがって，昔の人は機械を信頼 (trust) することができた。しかし，現在の機械は極めて高度化し， 複雑である。したがって，ユーザは，どのように動作するの か容易に理解できない。 また指示を出しても，予想したよう に機械が動作しない。したがって，機械への信頼がどんどん 低下している.」と述べている.

彼は，コンピュータサイエンスと心理学の教授である。彼 は，コンピュータについても，それを信頼できるかどうかは， 人間の心の反映 (reflection)であり, 感情的な評価が重要であ ると指摘している.

\section{6. システムの問題}

\section{1 ハードウェアとソフトウェア}

ハードウェアとソフトゥェアの個別の信頼性については極 めて多くの研究がなされ, 実用面でも多くの成果を上げてい る.しかし, 最近のシステムはハードウェア単独, ソフトウェ ア単独で使用される場合はまれで, 通常, 両者で一つのシス テムを構成する。この視点から，ハードウェアとソフトゥェ アの信頼性を考えると, 次の点が今後の大きな課題である.

ハードウェアは機能固定方式で生産される(図3).すなわ ち, 設計要求機能を実現して出荷する. 出荷後はハードゥェ アの機能は劣化する。したがって, いかに設計段階のレベル まで戻すか, すなわち保守が, 重要となる.

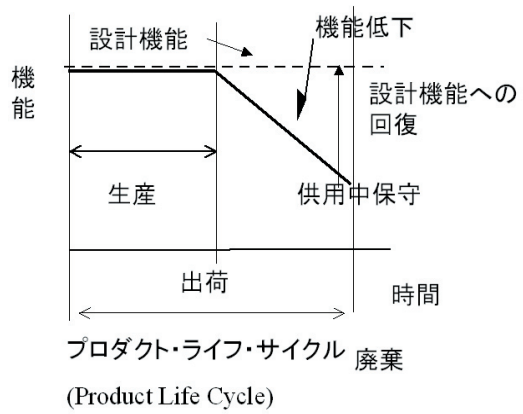

図3 機能固定方式 ハードウェア

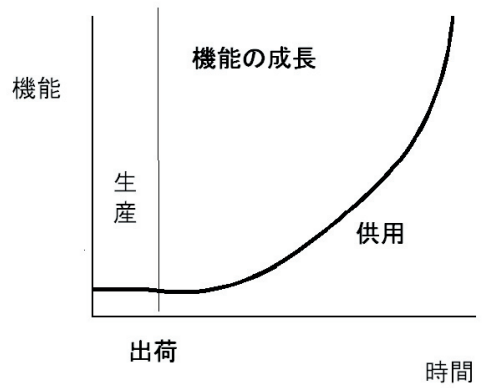

図4 機能成長 (進化) 方式 ソフトウェア

従来のハードウェアの信頼性は, 出荷までの信頼性確保が 主眼であった。もちろん, 保守の重要性は指摘され, 非破壊 検査などの発達も著しい。しかし, 非破壊検査も対象の性状 が分かれば高度なレベルで検出できるが, 対象が不明な場合, 正常と異常を検出することは容易ではない，そのため, 現在 でも航空分野では目視検査, プラントではウォークスルーが 欠かせない。ただ, 正常状態と異常状態の識別が容易な場 合は, 正常状態を常時監視し, それから逸脱すれば, 保守が 必要と判断できる。もちろん，その場合も，個別分野での経 験の蓄積が必要である。このような対応は, 最近 prognostics として急速に盛んになってきた。しかし, それらは, 設計機 能の維持が目的である.

これに対して, ソフトウェアは機能成長 (進化) 方式である (図4)。ソフトゥェアも, 以前はハードゥェア同様, 機能固 定方式で生産されていた。しかし, 知識工学により継続的プ ロトタイピングの概念が広まり, 現在は機能成長 (進化) 方式 となった。

ソフトゥェアも当初は個別のソフトの機能を継続プロトタ イピングの考え方により「成長させる」方式であった.しかし， 多様なCOTS (Commercial Off The Shelf) が提供される時代と なり，今は，機能を「進化させる」時代となった。

ハードゥェアは物理的な存在であり，いわば個別の生命体 である。これに対してソフトウェアは，種として進化する。 すなわち, ハードウェアでは, 太郎君, 次郎君の問題を考え なければならない。これに対してソフトウェアは人類全体を 考えている。太郎君には寿命があるが，人類は種としては， 進化し永続してゆく，実際ソフトウェアでは現在システム寿 命の決定 (decommissioning) が大きな問題となっている. 現状 では, ソフトゥェアの使用停止時期の決定は, ハードウェア の劣化 (物理的, 性能的)を基礎にしている.

また，ハードウェアは物理的な存在で, ソフトウェアは非 物理的な存在である. ハードウェアの場合は, 人間の五感と 直接結び付くので, 評価も容易であり, 信頼性向上のための 対応も比較的立てやすい. しかし, ソフトウェアは非物理的 な存在であるだけに，信頼を生むためには，いかに人間の五 感と結び付けるが重要となる。これは, 人間同士が会話をし ているときに，信頼できるかどうか感じさせることと基本的 に同じである，機能的な信頼性ではなく, Normanも指摘す るように, 感情的に信頼を置けるかが重要となってくる。 そ の意味で心理的な信頼性をソフトウェアでは今後もっと考慮 
する必要がある.

このような相違のあるハードウェア，ソフトウェアをどの ように協働させるかはこれからの大きな課題である.

\section{2 線形モデルからループモデルへ}

ハードウェアとソフトウェアの生産方式は, 線形モデルと ループモデルとも区別できる。線形モデルでは，設計一試作 (プロトタイプ) 一生産一使用とプロセスが逐次的に処理され る(図5)。この方式は，18 世紀から19世紀の産業革命以降に 定着した。産業革命を契機に効率的な製品実現を指向して， 専門化が進んだ。

ソフトウェアの継続的プロトタイピングは，ループモデル である(図6)。この図を見れば分かるように，これは，品質 の分野でよく使用される，元々 Walter A. Shewhartが考え出し た，デミングサイクル（図7）と基本的に同一である。その基 本は，絶えざるフィードバックと，行動の中で考えることで ある。すなわち, 行動から学び, 次の行動へとつなげる方式 である.

デミングサイクルの考え方は, Donald Schonが提案した Reflective Practice, Thinking in Action と同じ考え方である ${ }^{(14)}$. Schonは，社会状況が大きく変化した1980年代に，それまで の理論を適用する考え方 (演繹的な考え方)では，対応できな い分野として，経営，設計，医療などを挙げ，それらの分野 の専門家は日々の実践から学び, 次の日の行動を決めている

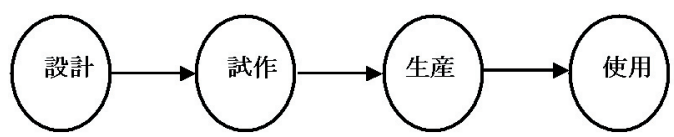

図5＼cjkstart線形モデル（プロトタイプは試作）

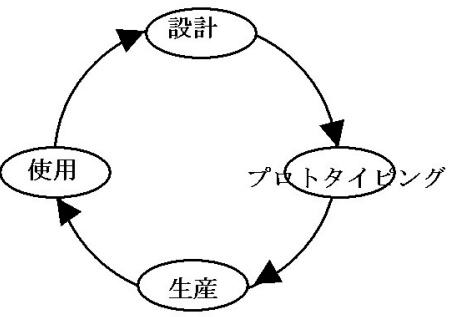

図6 継続的プロトタイピング

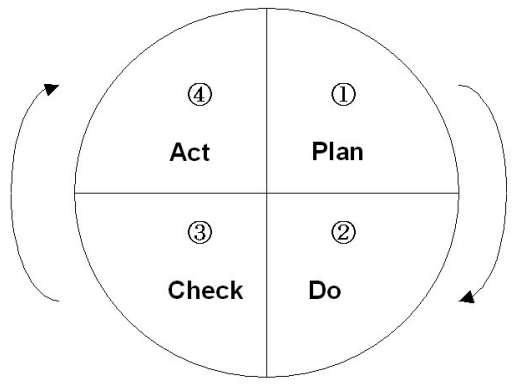

図7 デミングサイクル
と指摘し, 行動の中の知と呼んだ.

この考え方の背景にはアメリカのP Pragmatismが，またその 源泉には，イギリスの哲学がある。イギリスは航海で世界に 発展した。アメリカも開拓の歴史が背景にある. Pragmatism を生んだとされるCharles A. Peirceの Abduction は帰納法とは 異なる第3の論理である。その考え方は，観察される事象の 集合から妥当と思われる仮説を導き, それを適用することで, 演繹的な解決を図るＳＣhonの考え方も実は，Abductionに極 めて近い．また，Shewhartの方法論もPragmatismの考え方に 近いことが指摘されている.

アメリカの西部開拓では, 明日の世界は未知である。した がって, 昨日までの経験の蓄積から, 未知の明日への対応を 考えてゆかなければならない。演繹的な方法では，それまで の経験, 知識を集積して, 体系化して, それらを適用してゆく。 適用する対象が，それらの経験，知識を集積した世界であれ ば有効である。しかし，航海，開拓では，明日は未知である。 しかも，Schonが指摘した設計は創造活動で，既存世界とは 異なる世界を作り出すのが本来の活動である. 21 世紀は既存 マーケットで戦う時代ではなく，マーケットを創造する時代 である。したがって，このような Reflectiveな考え方は今後極 めて重要となり, システム信頼性もこうした考え方で進めて ゆく必要がある。

残念ながら Reflective という言葉に適切な訳語がない。いわ ば作用に対する反作用, 反応である。作用, 反作用もループ を形成する。既述のように，NormanはEmotional Designの中 で, emotionは reflectionから起き, 期待 (expectation)にこたえ ることが信頼 (trust) を形成する上で重要であると指摘してい る.

これは，何か行動をしたときの反応 (reflection) から感情 が喚起され，それらの経験の集合から, abductionと同じよ うな思考過程を経て，一種の期待 (論理ではそれを仮説と呼 んでいるが）を構成するのであろう。そのように考えると， Normanが指摘する Emotional Design と Charles A. Peirceが提唱 する abductionの考え方は非常に類似している.

21 世紀は, 明日が未知の世界である。安全, 安心への関心 が最近非常に高いのは，21世紀が開拓の時代だからである. 未知の技術がどんどん開発され，極めて短時間で実用化され てマーケットに投入される。以前は，製品のライフサイクル

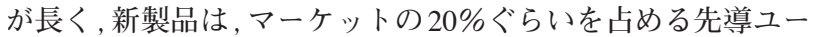
ザグループによってまず購入された。そして, 先導グループ の使用実績, 評価を見て, 残りの $80 \%$ が購入した。しかし， 現在は製品のライフサイクルの短縮化が急激に進み，新製品 の使用実績がまだマーケットで確定しないうちに次の新製品 がマーケットに出現する状況である。

したがって，ユーザは未体験の，見えない技術で開発され たシステムに囲まれ，不安が増大している。

このような状況でユーザに新製品を購入してもらうために は，技術を可視化しなければならない。またどうすれば，適 切な期待を持たせられるかが重要となってくる。すなわち, これまでは，製品をマーケットに投入すれば，その品質，信 
頼性をユーザが判断できた。しかし，製品ライフサイクルが どんどん短縮化し, マーケットを創造する時代となると, マー ケットに製品を投入する以前に信頼を確保しなければならな い.

品質, 信頼性は数值ではない. ユーザの評価が信頼 (trust) を生む. 数值の信頼度は, 生産者の判断指標にしかすぎない. ユーザにとっては何の意味もない.ユーザが受け入れられる か, ユーザにとって価值があるかどうかが, 21 世紀の品質で あり，信頼性である.

この意味で, 21 世紀の信頼性工学では, 期待技術の開発が 重要となる。すなわち, ユーザに適切な期待感を持たせ，そ れを製品として実現し提供することが信頼 (trust) を生む。こ の期待感とは，単なる新技術の出現に対する期待だけではな い. 製品, システムが, 自分が考えているように動作するか どうかが，大きな影響を及ぼす。

21 世紀のシステム信頼性では，信頼感，価值の創造が極 めて重要となってくる。そのために, 適切な期待の醸成, それに対応する製品の提供が重要な課題となる。そこで は, reflectionが重要な役割を果す。 21 世紀の信頼性工学は, reflective engineering あるいは, reflective reliabilityとでも呼ぶ ベきものとなると考えられる。

\section{7. 鳔境の問題}

\section{1 時間一文眽}

最後に環境の問題を考える。従来の工学は, 再現性の実現 に努力を払い，また，できるだけムダを排除してきた。すな わち, 文脈独立の考え方が基本である. SHELモデルでも文 脈の問題は明示的に論じられていない。しかし，これからは 文脈の考慮が不可欠となる.

従来, 文脈独立の考え方が有効であった理由は, 状況変化 が極めて緩やかだったからである。しかし, 状況変化が激し くなれば，文脈独立では対応できない。実際，ムダも，ある 視点から見たときにムダなのであり，他の視点から見れば非 常に有用である場合も少なくない。これはロバストネスの問 題である.

\section{2 空間一遍在知}

ユビキタスコンピューティング, アンビエントインテリ ジェンス (ambient intelligence) が急速に発達している。この ような技術が進めば，知として，これまでの暗黙知，形式知 以外に遍在知を考える必要がある。

形式知とは，マニュアル化できる知識である。これまでの 信頼性はマニュアル化できる形式知を主として対象としてき た。しかし, Michael Polanyi ${ }^{(16)}$ は, こうして形式化できる以 外の知があることを指摘した。例えば，自転車の乗り方をい かにマニュアルで教えても, 乗り方を教えることはできない. 自転車に実際乗って習うことが一番早い. 知の中には, この
ように形式化できない知が少なくない，技能，ワザはその典 型である.

これまで, 信頼性工学では, こうした暗黙知とされる技能, ワザについて余り考慮を払ってこなかったといっても過言で はない。それは, 従来の信頼性工学が設計者中心で, ユーザ 中心ではなかったからである。例えば, LOFTは, こうした 技能を修得する訓練であり, シミュレータなどが信頼性向上 に果す役割はユーザ中心の信頼性では非常に重要な役割を果 す.

形式知も暗黙知も知は人間の頭や身体にあると考えてい る.しかし, コンピュータが遍在する世界となれば, システ ムは外界環境と統合され, ユーザの行動傾向, 性格などから, ユーザの期待を察知し，それに応じた情報を提供できる。い わば, 外界に知が遍在することになる。ユビキタスコンピュー ティングは, コンピュータの遍在を指しているが, それによ り知が遍在する事実に注目した名称がアンビエントインテリ ジェンスである.

このような遍在知により, 環境情報の提供だけではな く, ユーザの意罒理解が的確にできるようになる。したがっ て, システムとの対話を通して, ユーザはシステムへの信頼 (trust) を深めるであろう.

\section{8. おわりに}

多様化, 状況変化が急激に進む現在, システム信頼性の研 究は, これまでの設計者中心から, ユーザ中心へと移行して いる。すなわち，これまでの文脈独立のコマンド方式から脱 却し, 状況を察知し, ユーザの意図, 期待を推定し, それに 対応できる文脈依存のシステムを開発することが今後の大き な課題である。ユビキタスコンピューティングなどの技術が そのために大きな役割を果すと期待されるが, その効果を上 げるためには, 人間の特性に注目した研究を更に進める必要 がある。

\section{文献}

（1）例えば,

http://en.wikipedia.org/wiki/Aviation_accidents_and_incide nts

(2) G.E. Cooper, M.D. White, and J.K. Lauber, J.K. "Resource management on the flightdeck," Proceedings of a NASA/Industry Workshop (NASA CP-2120), NASA Ames Research Center, Moffett Field, CA, 1980.

(3) H. F. Hawkins, Human Factors in Flight, Gower Technical Press. Ltd, 1987.

ヒューマン・ファクター, 黒田 勲(監修), 石川好美 (監訳), 成山堂書店, 1992.

（4）福田収一，ものづくり大論, 丸善, 2006.

(5) P. Salovay, J.D. Mayer, “Emotional Intelligence," Imagination, Cognition and Personality, vol.9, pp.185-214, 1990.

（6）例えば,

http://en.wikipedia.org/wiki/United_Airlines_Flight_232

(7) http://en.wikipedia.org/wiki/Line_Oriented_Flight_Train ing

（8）福田収一, 価值創造学, 丸善, 2005.

(9) C. Anderson, The Long Tail: Why the Future of Business Is Selling Less of More, Hyperion, 2006. 
（10）「暖かい認知」の心理学, 海保博之 (編), 金子書房, 2002.

(11）東京都立科学技術大学の福田収一研究室とトヨタ自動車の共 同研究 (江尻綾美, 2002, 江成司, 市川真規, 小池 敦, 2003 の修士論文)。

(12) C. M. Jones and I.M. Jonsson, "Automatic recognition of affective cues in the speech of car drivers to allow appropriate response," Proc. 19th HCI, ACM, pp.1-10, 2005.

(13) D.A. Norman, Emotional Design, Basic Books, 2004.

(14) D.A. Schon, The Reflective Practitioner: How Professionals Think in Action, Basic Books, 1983.

（15）飯野謙次，D. Wild, “ユングの性格論を利用したチーム形成,” 機械の研究, vol.59, no.1, pp.155-162, 2007.

(16) M. Polanyi, Tacit Dimension, Peter Smith Pub. Inc, 1983.

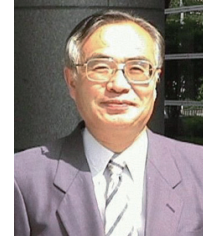

福田 収一(正員)

昭 42 東大・工・産業機械卒，昭 47 同大学院博士課程

修了 (工博)。東大助手, 阪大助教授, 東大 (併任) 助 教授，都立科技大教授，IEEE Reliability Society, Vice President (Technical Operations), 同日本支部長を歴任. 現在 Stanford University, Consulting Professor, 放送大 学客員教授, Cranfield University, Visiting Professor. 信頼性研究専門委員会前委員長. 人間ーシステムの チークワーキングの研究に従事. 日本工学教育協会賞 等受賞, 著書,「価值創造学」,「ものづくり大論」な ど 